\title{
Questions your patients may have about Zika virus
}

\author{
Zosia Kmietowicz
}

The BMJ

The World Health Organization has declared the Zika virus a public health emergency. The agency said that the evidence for a link between the virus and the increase in cases of babies with microcephaly and a spike in cases of Guillain-Barré syndrome was growing. ${ }^{1}$ Here is advice you can use to answer questions your patients may have about Zika virus.

\section{I'm pregnant and have a holiday planned to Guadeloupe next month. Should I go?}

Public Health England and the National Travel Health Network and Centre advise that women who are pregnant (any trimester) or who plan to become pregnant should consider avoiding travel to any area where active transmission of Zika virus is being reported (box). ${ }^{2}$ They say that if you can't avoid travelling to one of these countries you should take great care to avoid mosquito bites.

\section{What anti-mosquito measures should I use?}

The US Centers for Disease Control advises pregnant women to wear clothing that covers up as much of their body as possible (long sleeves, trousers, hat). ${ }^{3}$ It also advises travellers to use a good repellent on exposed skin during the day as well as at night and particularly during mid-morning and late afternoon to dusk, when the mosquito that transmits Zika is most active. Repellents that contain N, N-diethylmetatoluamide (DEET), picaridin, and IR3535 are all safe for pregnant women, provided that they follow the instructions, says the CDC. ${ }^{3}$ It says that if you need sunscreen you should apply repellent after sunscreen and should stay or sleep in a screened or air conditioned room or use a bed net.

\section{What are the symptoms of Zika virus infection?}

Most people infected with the Zika virus will not get symptoms, and if they do these are usually mild. Symptoms can include fever, rash, itching, joint pain, headache, muscle pain, eye pain, and conjunctivitis. ${ }^{2}$ There is no specific treatment, but you can take paracetamol for a fever and to ease any joint pain. However, if you're pregnant avoid aspirin and other non-steroidal anti-inflammatory drugs. ${ }^{3}$ If you're pregnant and think you have been infected with the Zika virus you can be tested.

\section{I'm a man and have just returned from a business trip to Mexico. My wife is pregnant. Is it safe to have sex?}

Most cases of Zika are acquired by mosquito bites, but the virus has been shown to be present in semen. The risk of sexual transmission of Zika is thought to be very low, but Public Health England advises men who have been in a country with Zika virus transmission to use a condom for 28 days. ${ }^{4}$ Men who have had an unexplained fever and rash that could have been caused by the Zika virus or have been told that they have Zika infection are advised to use a condom for six months.

\section{I'm pregnant and have recently returned from the Caribbean and I'm worried my baby could have microcephaly}

The Royal College of Obstetricians and Gynaecologists advises that women who've had no symptoms or whose symptoms have resolved should be referred for ultrasonography, which can be repeated every four weeks. ${ }^{5}$ Women with symptoms indicating Zika virus infection should have samples sent to the Rare and Imported Pathogens Laboratory (clotted blood, an EDTA "purple top" blood, and a small volume of urine without preservative). Women who test negative should be referred for ultrasonography, which can be repeated every four weeks. Women who test positive should be referred for ultrasonography and to fetal medicine for follow-up.

For all The BMSs latest articles on the Zika virus epidemic go to bmj. co/zika.

1 Gulland A. Zika virus is a global public health emergency, declares WHO. BMJ 2016;352:657.

2 Public Health England, National Travel Health Network and Centre. Zika virus: travel advice for pregnant women. Jan 2016. https://www.gov.uk/government/news/zika-virustravel-advice-for-pregnant-women.

3 Centers for Disease Control and Prevention. Interim guidelines for pregnant women during a Zika virus outbreak: United States, 2016. www.cdc.gov/mmwr/volumes/65/wr/mm6502e1. htm.

4 Travel Health Pro. Zika virus: update and advice for travellers including pregnant women. Feb 2016. http://travelhealthpro.org.uk/zika-virus-update-and-advice-for-travellers-includingpregnant-women.

5 Royal College of Obstetricians and Gynaecologists. Interim algorithm for assessing pregnant women with a history of travel during pregnancy to areas with active Zika virus (ZIKV) transmission. Jan 2016. https://www.rcog.org.uk/en/news/interim-clinical-guidelineson-zika-virus-infection-and-pregnancy. 


\section{Countries with active Zika virus transmission as at 29 January 2016}

- Barbados

- Bolivia

- Brazil

- Cape Verde

- Colombia

- Dominican Republic

- Ecuador

- El Salvador

- French Guiana

- Guadeloupe

- Guatemala

- Guyana

- Haiti

- Honduras

- Martinique

- Mexico

- Nicaragua

- Panama

- Paraguay

- Puerto Rico

- Saint Martin

- Samoa

- Suriname

- US Virgin Islands

- Venezuela

Further cases of Zika virus disease are expected to be reported in other countries where the mosquito vector is present, particularly in the Americas. 